\title{
Simpson-Golabi-Behmel syndrome types I and II
}

\author{
Jair Tenorio ${ }^{1,2}$, Pedro Arias ${ }^{1,2}$, Víctor Martínez-Glez ${ }^{1,3}$, Fernando Santos ${ }^{1,4}$, Sixto García-Miñaur ${ }^{1,4}$, Julián Nevado ${ }^{1,3}$ \\ and Pablo Lapunzina ${ }^{1,2,4^{*}}$
}

\begin{abstract}
Simpson-Golabi-Behmel syndrome (SGBS) is a rare overgrowth syndrome clinically characterized by multiple congenital abnormalities, pre/postnatal overgrowth, distinctive craniofacial features, macrocephaly, and organomegaly. Abnormalities of the skeletal system, heart, central nervous system, kidney, and gastrointestinal tract may also be observed. Intellectual disability, early motor milestones and speech delay are sometimes present; however, there are a considerable number of individuals with normal intelligence.

Genomic rearrangements and point mutations involving the glypican-3 gene (GPC3) at Xq26 have been shown to be associated with SGBS. Occasionally, these rearrangements also include the glypican-4 gene (GPC4). Glypicans are heparan sulfate proteoglycans which have a role in the control of cell growth and cell division.

Although a lethal and infrequent form (also known as SGBS type II) has been described, only the classical form of SGBS is reviewed in this work, whereas only some specific features on SGBS type II are commented.

We review all clinical and molecular aspects of this rare disorder, updating many topics and suggest a follow-up scheme for geneticists and primary care clinicians.
\end{abstract}

Keywords: Simpson-Golabi-Behmel Syndrome, Overgrowth, GPC3, GPC4, Macrocephaly, Rare disorders, Glypican, Congenital anomalies, $\mathrm{X}$-linked disorder

\section{Resumen}

El Síndrome de Simpson-Golabi-Behmel (SSGB) es un síndrome de sobrecrecimiento raro, que se caracteriza clínicamente por múltiples anomalías congénitas, sobrecrecimiento pre y post natal, rasgos craneofaciales distintivos, macrocefalia y organomegalia. Otras características que pueden presentar estos pacientes incluyen anomalías en el aparato esquelético, el corazón, el sistema nervioso central, el riñón y el tracto gastrointestinal. También pueden presentar discapacidad intelectual, retraso motor precoz y retraso en el habla, aunque en su mayoría, estos individuos presentan una inteligencia dentro de los límites normales.

Los reordenamientos genómicos y las mutaciones puntuales que incluyen el gen GPC3 ("Glypican-3 gene") localizado en la región cromosómica Xq26, se han asociado con la aparición del SSGB. Ocasionalmente, estos reordenamientos genómicos pueden incluir el gen GPC4. Los glipicanos son proteoglicanos de heparán sulfato que actúan controlando el crecimiento y división celular.

Aunque se ha descrito una forma letal de este síndrome (denominada SSGB tipo II) en esta revisión sólo analizamos la forma clásica de este síndrome y sólo comentaremos algunos aspectos del SSGB tipo II.

En este trabajo se presenta una revisión de todos los aspectos clínicos y moleculares de este síndrome, actualizando algunos aspectos y además se sugiere un esquema de seguimiento de estos pacientes por parte de genetistas y médicos de atención primaria.

\footnotetext{
* Correspondence: pablo.lapunzina@salud.madrid.org

${ }^{1}$ CIBERER, Centro de Investigación Biomédica en Red de Enfermedades Raras, ISCIII, Madrid 28029, Spain

${ }^{2}$ Molecular Endocrinology - Overgrowth Syndromes Laboratory, INGEMM, Instituto de Genética Médica y Molecular, IdiPAZ, Hospital Universitario la

Paz, Universidad Autónoma de Madrid (UAM), Madrid 28046, Spain

Full list of author information is available at the end of the article
} 


\section{Introduction}

The Simpson-Golabi-Behmel syndrome (SGBS) (OMIM 312870;ORPHA373) is an overgrowth/multiple congenital anomalies syndrome caused by mutations in a semidominant X-linked gene encoding Glypican 3 (GPC3). It shows high clinical variability (Table 1 ), ranging from very mild forms in carrier females to lethal forms with failure to thrive in males. The most consistent findings in SGBS are pre- and postnatal overgrowth, characteristic facial anomalies and abnormalities affecting the internal organs, skeleton, and in some occasions, variable degree of intellectual disability. SGBS is also associated with an increased risk of developing embryonal tumors (Table 1), mostly Wilms and liver tumors. About 250 patients have been reported so far in the medical literature. The prevalence of the syndrome is unknown.

To date, two different clinical subtypes of SGBS have been described. The classical SBGS (also known as SGBS type I) [1-4] and a lethal and infrequent form (probably with less than 10 cases described; also known as SGBS type II. OMIM 300209; ORPHA79022) described by Terespolsky et al., in $1995[5,6]$.

In this work we review all aspects of the classical form of SGBS. Due to the scant number of patients reported with SGBS type II, only some minimal aspects of this disorder are commented in this manuscript.

\section{Disease definition}

SGBS was initially described by Joe Leigh Simpson and coworkers in 1975 [1]. In 1984, Golabi and Rosen [3] and Behmel et al. [2] independently reported further cases. Neri et al. [4] described additional cases, put all these reports together and named the disorder "SimpsonGolabi-Behmel syndrome". The old terms "Golabi-Rosen syndrome", "Gigantism-dysplasia syndrome", "Encephalotropho-schisis syndrome" and "Simpson dysmorphia syndrome" and the pejorative "Bulldog syndrome" are no longer in use for SGBS and should be avoided.

\section{Epidemiology}

SGBS syndrome is a rare overgrowth disorder, less common than the Beckwith-Wiedemann and Sotos syndromes. The birth prevalence is unknown. Approximately 250 cases are known to date.

\section{Clinical description}

There are at least two different clinical subtypes of SGBS. The classical form (SGBS or SGBS type I) associated to mutations in GPC3 and a lethal form (SGBS type II) associated to a different region of chromosome X (Xp22.2) [5]. The lethal form is an infantile lethal variant of SGBS usually associated with hydrops fetalis.

\section{Clinical findings \\ Clinical subtypes of SGBS}

There are two different clinical subtypes of SGBS. The classical SBGS (also known as SGBS type I) [1-4] and a lethal and very infrequent form (known as SGBS type II. OMIM 300209; ORPHA79022) described by Terespolsky et al., in 1995 [5,6]. Clinical findings below correspond mainly to those features observed in classical SGBS type I. Due to the phenomenon of Lyonization; some female carriers may have mild physical findings of SGBS. Some carrier women are tall, have extranumerary nipples, coarse face, abnormal hands and midline defects.

\section{Skull}

Macrocephaly is observed in about $70 \%$ of children with SGBS. Craniosynostosis has been reported in many cases $[7,8]$.

\section{Face}

The face in patients with SGBS is square and coarse. The forehead is large and the nose and lips are usually large and thick. Cleft lip and/or palate is observed in about 13\% of cases. The tongue is wide and with a middle groove from the tip to the back of the tongue [9-11] (Figure 1). There may be midline minor anomalies such as subcutaneous lipomas, pits or flat nevus flammeus. Multiple odontogenic keratocysts were reported in one patient [12].

\section{Neck}

Laryngeal web [13] and airway and swallow manifestations were reported in a minority of children [14].

\section{Heart}

Diverse cardiovascular malformations have been reported in patients with SGBS, and it is suspected that they are related to the apparently high incidence of early death [15]. Lin et al. [15] reviewed 101 SGBS patients and demonstrated that $36 \%$ had a cardiac abnormality, of which 26 had a cardiovascular malformation. Most cases (77\%) were class II CVMs (attributed to altered embryonic intracardiac flow). Other cardiac abnormalities included cardiomyopathy $(\mathrm{n}=4)$ and electrocardiogram $(\mathrm{ECG})$ conduction or rhythm abnormalities. Death was associated with a cardiac abnormality in $23 \%$ of patients. The authors conclude that cardiac abnormalities of any type are common in SGBS [15].

\section{Vascular findings}

Carotid artery dissection in an adult [16], hepatic vascular malformations [17] and diffuse neonatal hemangiomatosis has been associated with SGBS [18]. 
Table 1 Clinical findings in Simpson-Golabi-Behmel Syndrome Type I (SGBS Type I)

\begin{tabular}{ll}
\hline 1. Craniofacial features & \\
\hline Skull & $\begin{array}{l}\text { Macrocephaly in 70\% of children. } \\
\text { Craniosynostosis is observed in } \\
\text { many of the cases } \\
\text { Face }\end{array}$ \\
& $\begin{array}{l}\text { Square and coarse. Large forehead. } \\
\text { Cleft lip or palate in 13\% of the patients. } \\
\text { Wide and middle groove tongue }\end{array}$ \\
Nose and lips & $\begin{array}{l}\text { large and thick } \\
\text { Cleft palate is present in about 13\% } \\
\text { Palate }\end{array}$ \\
of the patients \\
Tongue & $\begin{array}{l}\text { Wide and middle groove from the tip } \\
\text { to the back }\end{array}$
\end{tabular}

\section{Tumors}

Tumor risk

Wilms tumor, hepatoblastoma, adrenal neuroblastoma, gonadoblastoma and hepatocellular carcinoma has been described in patients with SGBS

3. Cardiovascular abnormalities

\begin{tabular}{|c|c|}
\hline Cardiac abnormalities & $\begin{array}{l}\text { Any type of cardiac abnormalities are } \\
\text { very common in SGBS }\end{array}$ \\
\hline Cardiovascular malformations & Altered embryonic intracardiac flow \\
\hline Cardiomyopathy & In about $4 \%$ of the cases \\
\hline $\begin{array}{l}\text { Conduction or rhythm } \\
\text { abnormalities }\end{array}$ & In a low percentage of patients \\
\hline Carotid artery dissection & One case has been described \\
\hline ECG abnormalities & In about $12 \%$ of the patients \\
\hline \multicolumn{2}{|l|}{ 4. Abdominal region } \\
\hline Visceromegaly & $\begin{array}{l}\text { Nephromegaly, splenomegaly } \\
\text { and hepatomegaly is common }\end{array}$ \\
\hline $\begin{array}{l}\text { Congenital Diaphragmatic } \\
\text { Hernia }(C D H)\end{array}$ & $\begin{array}{l}\text { Was observed in less than 10\% } \\
\text { of the cases reported }\end{array}$ \\
\hline Neonatal liver disease & $\begin{array}{l}\text { One patient has been described. Finally } \\
\text { developed early biliary cirrhosis }\end{array}$ \\
\hline $\begin{array}{l}\text { Choledochal cyst, } \\
\text { biliary cirrhosis }\end{array}$ & Only reported in 1 patient \\
\hline \multicolumn{2}{|l|}{ 5. Genitalia } \\
\hline Hypospadias & \multirow{3}{*}{$\begin{array}{l}\text { These three features have been reported } \\
\text { in a low percentage of the patients }\end{array}$} \\
\hline Cryptorchidism & \\
\hline Penoscrotal transposition & \\
\hline \multicolumn{2}{|l|}{ 6. Skeletal } \\
\hline Index finger & Hypoplasia \\
\hline Proximal phalanx & Congenital abnormality \\
\hline Syndactyly & 2nd-3rd finger \\
\hline Rib malformations & Frequent \\
\hline Sella turcica & Deep V-shaped \\
\hline Six lumbar vertebrae & Exceptional \\
\hline
\end{tabular}

\section{Central Nervous System (CNS)}

Hydrocephalus

Epilepsy

Obstructive sleep apnea syndrome
Table 1 Clinical findings in Simpson-Golabi-Behmel Syndrome Type I (SGBS Type I) (Continued)

\begin{tabular}{ll}
\hline $\begin{array}{l}\text { Attention deficit hyperactivity } \\
\text { disorder }\end{array}$ \\
\begin{tabular}{ll}
\hline 8. Speech and language & \\
\hline Distorted articulation & $\begin{array}{l}\text { Distorted resonance has been } \\
\text { also described }\end{array}$ \\
Fluency failures & \\
Stereotype prosody & \\
\hline 9. Other & Laryngeal web and airway swallow \\
\hline Neck &
\end{tabular} \\
\hline
\end{tabular}

\section{Arrhythmias}

Data are insufficient to define a cardiac phenotype/molecular correlation [15]. Lin et al. [15] reviewed 101 cases and reported that $12 \%$ of cases had ECG abnormalities, $25 \%$ of whom had an underlying cardiovascular malformation. Out of the 29 deaths in Lin and coworkers' review [15], 9 (31\%) were associated with a structural cardiac abnormality, and only one was associated with an ECG abnormality (partial right bundle branch block). Although previous reports indicate neonatal mortality in affected males with SGBS to be as high as 50\% [4], there is no clear evidence that arrhythmias have the major role in neonatal mortality without the presence of a major cardiac malformation. There are sufficient data to recommend a baseline echocardiogram and ECG in SGBS patients.

\section{Thorax}

Besides cardiovascular anomalies, supernumerary nipples are common in both affected individuals and carrier females (Figure 1).

\section{Abdominal region}

Visceromegaly (nephromegaly, splenomegaly and hepatomegaly) is quite common. Congenital diaphragmatic hernia (CDH) [19] is observed in less than $10 \%$ of children. Neonatal liver disease leading to an early biliary cirrhosis has been reported in one individual who finally needed liver transplantation [20]. Choledochal cyst is also reported in one patient [21].

\section{Genitalia}

Hypospadias, cryptorchidism and penoscrotal transposition have been observed in some individuals [22]. In one patient cryptorchidism also associated chordee of the penis (Figure 1).

\section{Intellectual disability}

Intellectual disability may be present in this disorder. Patients must be carefully evaluated because most of them may have normal intelligence instead of the coarse facial features and difficulties in speech. 


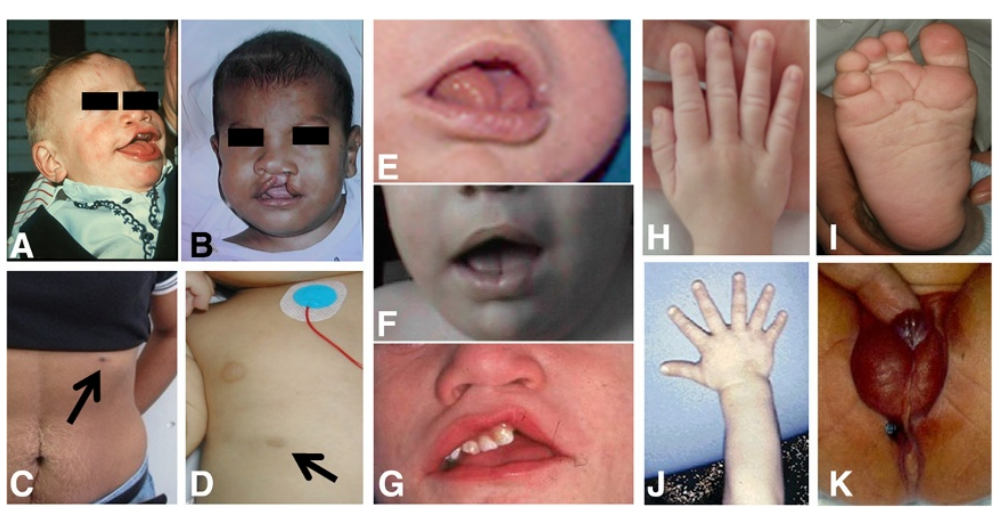

Figure 1 Clinical findings in Simpson-Golabi-Behmel syndrome. A and B: Facial phenotype. Note the cleft lip, coarse, square face and broad nose. $\mathbf{C}$ and $\mathbf{D}$ : extra-nipple in a carrier mother and a toddler. $\mathbf{E}, \mathbf{F}$ and $\mathbf{G}$ : close up of the mouth of three different patients. Note the large tongue, middle groove in the tongue, teeth malposition and repaired cleft (in $\mathbf{G})$. $\mathbf{H}$ and $\mathbf{J}$ : Hands. Note broad hands and polydactyly in one subject. I: Deep plantar creases. K: abnormal genitalia in a male with hypospadias and proximal anal placement. Written informed consent was obtained from the parents of the patients for publication of their photographs.

\section{Speech and language}

Speech was characterized by a distorted articulation, distorted resonance, fluency failures, and stereotype prosody [23].

\section{Skeletal}

Marked index finger hypoplasia and a congenital abnormality of the proximal phalanx [24] and of the same fingernail, and 2nd-3rd finger syndactyly [25] is observed in many patients. Polydactyly (postaxial) may be found in a minority of individuals (Figure 1). Other skeletal findings include rib malformations, deep V-shaped sella turcica and six lumbar vertebrae [26].

\section{CNS}

Generalized hypotonia is one of the main clinical findings in SGBS. Hydrocephalus, epilepsy [27], obstructive sleep apnea syndrome [28] and attention deficit hyperactivity disorder may be present [29].

\section{Genotype-phenotype correlations}

There is no genotype-phenotype correlation. In a study of genotype-phenotype correlations, Mariani et al. [30] determined that all deletions and point mutations occurring in the eight GPC3 exons result in loss of function with no phenotypic distinctions based on size or position of a deletion or point mutation [31].

\section{Penetrance}

The penetrance is $100 \%$; all males with a GPC3 mutation have had clinical findings of SGBS. Penetrance in heterozygous females is not known.

\section{Tumor risks and tumor predisposition}

Affected individuals with SGBS are at increased risk for embryonal tumors, including Wilms tumor, hepatoblastoma, adrenal neuroblastoma, gonadoblastoma, and hepatocellular carcinoma. A review of the main tumors (Wilms, gonadoblastoma, neuroblastoma and liver tumors) observed in SGBS patients have been reported in 2005 [32]. Kosaki et al. [33] reported a SGBS patient with hepatoblastoma and a CTNNB1 somatic mutation (p.Ile35Ser) together with a germline loss-of function mutation in GPC3. Since the CTNNB1 mutation in the tumor tissue represents a driver mutation, these data suggest that mutation in GPC3 may influence one of the initial steps in tumorigenesis and the progression to hepatoblastoma. Other patients with SGBS and hepatoblastoma [33,34] both at age 9 months, [35] and at 14 months have been also described. Hepatocarcinoma is less common [11]. Metastatic medulloblastoma in an adolescent has been published [36].

\section{Etiology \\ SGBS type I}

After the mapping efforts done for some groups [37] a translocation [38] in a woman with an X-autosome translocation led to the recognition of GPC3 as the gene responsible of the disease. Most cases follow an X-linked inheritance though some cases are de novo. There is at least one family with germinal mosaicism [39]. Deletions, duplications and point mutations of GPC3 have been reported in patients with SGBS type I. There is only one report of a duplication of GPC4 [40]; thus, the role of this gene in the pathogenesis of SGBS type I needs further investigations and evidences. No point mutations of GPC4 were reported so far in individuals with SGBS type I.

\section{SGBS type II}

There are a small number of reports on this rare form of the disease $[5,6,41]$. It is an infantile lethal variant of SGBS associated with hydrops fetalis. In the first report, 
the authors reported 4 maternally-related male cousins with a severe variant of SGBS [6]. One of these males was aborted therapeutically at 19 weeks of gestation following the detection of multicystic kidneys on ultrasound. The three live born males were hydropic at birth. They also depicted craniofacial anomalies including macrocephaly; apparently low-set, posteriorly angulated ears; hypertelorism; short, broad nose with anteverted nares; large mouth with thin upper vermilion border; prominent philtrum; high-arched and cleft palate. Other findings were short neck; redundant skin; hypoplastic nails; skeletal defects involving upper and lower limbs; gastrointestinal and genitourinary anomalies, hypotonia and neurologic impairment. All patients died within the first 8 weeks of life. SGBS type II maps to Xp22 and is postulated to be a distinct disorder with overlapping phenotypic features. Budny et al. [41] identified a CXORF5 (also called as OFD1) mutation in one family with some clinical findings suggestive of SGBS type II but further analysis of 17 patients with clear phenotypic features of SGBS and negative for GPC3 mutations found no mutations in CXORF5 [42]. Thus, CXORF5 is not clearly associated to SGBS type II.

\section{The gene and proteins in the pathway}

Glypicans (GPCs) are a family of proteoglycans that are bound to the cell surface by a glycosylphosphatidylinositol anchor. Six glypicans have been found in the mammalian genome (GPC1 to GPC6). GPCs regulate several signaling pathways [43]. Given the critical role that insulin-like-growth factor II (IGF-II) plays in the regulation of embryonic growth, it was initially proposed that GPC3 was an inhibitor of IGF-II, and that the overgrowth observed in the SGBS patients was due to an increase in IGF-II signaling caused by the loss of functional GPC3. However, GPC3 does not interact with IGF-II, GPC3-null embryos display normal levels of IGF-II [43-45] and the fact that the crossing of the GPC3-null mice with various mouse strains that lacked critical components of the IGF signaling pathway did not show any genetic interaction [46] gave a definitive proof that overgrowth in SGBS patients is independent of IGF. Capurro et al. hypothesized that GPC3 acts as an inhibitor of Hedgehog (Hh) signaling in the embryo, and that the overgrowth found in SGBS patients is due, at least in part, to hyperactivation of hedgehog signaling caused by the loss of functional GPC3, which was demonstrated by the finding that hedgehog signaling activity is elevated in GPC3-null mice [47]. The binding of $\mathrm{Hh}$ to GPC3 triggers the endocytosis and degradation of the GPC3/Hh complex [47]. Additional evidence that GPC3 is a negative regulator of Hhsignaling was recently provided by some experiments performed in cultured Drosophila cells [43,48].

\section{Diagnosis}

\section{Diagnostic criteria}

The major diagnostic criteria are: overgrowth (macrosomia, macrocephaly and/or pre-and postnatal overgrowth), coarse, characteristic facial appearance, midline defects and tumor predisposition (Table 1). Other findings are organomegaly, anomalies of the skeletal system, and congenital malformations of the heart, central nervous system, kidney, and gastrointestinal tract. Intellectual disability of variable degree may be present.

\section{Diagnostic methods}

Diagnosis is suspected on the clinical findings, pedigree analysis and medical problems of patients. Genetic approach currently includes a karyotype focusing on the $\mathrm{X}$ chromosome, array CGH and/or MLPA analysis and mutation analysis of the GPC3/GPC4. Next generation sequencing technologies have allowed the simultaneous testing of many genes responsible of overgrowth through panels of genes or directly through whole exome sequencing [49].

\section{Laboratory and medical imaging findings}

No biochemical or endocrinological pathognomonic markers have been documented in patients with SGBS. Central nervous system findings on CT scan or brain MRI are common; midline defect such as abnormal corpus callosum, central lipomata, and hydrocephalus may be present. On X-rays are very useful a typical sign of index finger hypoplasia and a congenital abnormality of the proximal phalanx [24] and of the same fingernail. Rib malformations are usually observed in most patients.

\section{Differential diagnosis}

SGBS belongs to a group of overgrowth syndromes that have some clinical features in common such as pre- and/ or postnatal overgrowth and in some of them cancer predisposition. SGBS syndrome has clinical overlap with other overgrowth syndromes, in particular with BeckwithWiedemann syndrome. Beckwith-Wiedemann syndrome due to CDKN1C mutations demonstrates the highest clinical similarities with SGBS, including genitourinary malformations, an increased incidence of embryonic tumors, macrosomia, macroglossia, coarse face and ear anomalies. However, the mode of inheritance of SGBS may help to differentiate these disorders. Other entities that should be considered in the general differential diagnosis of SGBS syndrome are: Weaver syndrome, Perlman syndrome; Fragile X syndrome; Bannayan-Zonana syndrome; PTEN hamartoma tumor syndrome; Marshall syndrome, Nevo syndrome; Neurofibromatosis type I; Marfan syndrome; nevoid basal cell carcinoma syndrome (Gorlin syndrome), Fryns syndrome, Elejalde syndrome (acrocephalopolydactylous dysplasia), mosaic trisomy 8, 
Pallister-Killian syndrome and trisomy 15q26-qter [50]. Many of these syndromes can be easily excluded on the base of other major clinical features, pedigree analysis and mode of inheritance.

\section{Genetic counseling Parents}

SGBS is inherited in an X-linked fashion. If there is only one affected individual in a family, the patient may have inherited the mutation from his mother or may have a de novo mutation. Reviewing all published cases of SGBS indicates that the frequency of de novo mutations is about $20-30 \%$. In families with more than one affected individual, the mother of an affected male may be a carrier (most probably) or may have germline mosaicism (rarely). Chromosome analysis (including FISH) and aCGH/MLPA of the mother needs to be performed when a deletion of GPC3 is detected in the affected child. Molecular tests looking for point mutations through sequencing methods (Sanger, NGS, etc.) should be warranted for every mother of molecularly-confirmed individual. Germline mosaicism is extremely rare and has been reported in only one family [39].

\section{Sibs}

The risks of brothers and sisters of a patient will depend on the status of the mother. If the mother of a patient is carrier of the molecular defect, the probability of transmitting the disease in each pregnancy is $50 \%$. Brothers who inherit the mutation will be affected by the disorder and sisters who inherit the mutation will be carriers and will usually not be affected or show minimal clinical findings of SGBS [50].

\section{Offspring}

Male SGBS patients will transmit the GPC3 mutation to all of their daughters and none of their sons that will not be affected by the disease. Daughters of affected male patients will be carriers.

\section{Antenatal diagnosis and preimplantational genetic testing Ultrasound examination}

Ultrasound approach is possible in families at risk of SGBS [50-52]. Increased nuchal translucency and other ultrasound findings such as macrosomia, cleft lip or palate, nephromegaly, macroglossia and hydrops/ascites may suggest the fetus is affected [7,53]. The finding of disproportionate fetal overgrowth together with elevated maternal serum alpha-fetoprotein is also useful to suspect SGBS [19].

\section{Molecular tests}

Once the mutation has been identified in a patient or any family member, prenatal diagnosis and/or preimplantational genetic testing is possible for at-risk pregnancies [50].

\section{Management \& treatment General management}

It includes treatment of neonatal hypoglycemia and multidisciplinary support of many pediatric specialists such as cardiologist, neurologist, and orthopedist. Specific management and follow-up of tumors should be warranted to all individuals with SGBS (see below).

\section{Management for males with SGBS}

- Monitoring for hypoglycemia in the newborn period.

- Physical examination to monitor for scoliosis during period of rapid growth rate; radiographs as needed.

- If development appears to be normal on initial assessment, routine monitoring of social and intellectual development.

- Monitoring of renal function if renal anomalies are present.

- Physical examinations to monitor for tumor risk [32]: a) Every three months until age four years;

b) Every four months from age four to seven years;

c) Biannually after seven years of age.

Main tumors to be screened are: 1) Wilms and liver tumors: Abdominal ultrasound examination every three and four months from birth until at least age seven and yearly there after $[32,54]$. Abdominal ultrasound examination should assess for both Wilms tumor and hepatic tumors. Similarly to Beckwith-Wiedemann syndrome, the risk for Wilms tumor seems to decrease after eight years of age; 2) Gonadoblastoma. Serial measurements of serum alpha fetoprotein and beta human chorionic gonadotropin concentrations (also for hepatoblastoma) is recommended [32]; 3) Neuroblastoma. Measurements of urinary catecholamine metabolites including vanillylmandelic acid and homovanillic acid as well as urinary free fractionated catecholamines [32] and annual lifelong chest radiograms have also been suggested for chest tumors [32].

\section{Prognosis}

The spectrum of signs and symptoms associated to SGBS is broad, varying from very mild forms in carrier females to infantile lethal forms in affected males. A percentage of affected males die in the newborn period, some of them probably due to heart defects. Carrier females and people with milder cases often live into adulthood. Because of the varying degrees of manifestations and severity associated with the condition, prediction of prognosis and life expectancy most likely varies on an individual basis.

Intellectual disability must be carefully evaluated due to the majority of patients have normal intelligence, and do not have the coarse facial and difficulties in speech as we expected for classical SGBS. 


\section{Abbreviations}

$\mathrm{CDH}$ : Congenital diaphragmatic hernia; CDKN1C: Cyclin-dependent kinase inhibitor 1C; CNS: Central nervous system; CT: Computed tomography; CTNNB1: Catenin (Cadherin-Associated Protein) Beta 1; CVMs: Cardiovascular malformations; CXORF5 (OFD1): Oral-facial-digital syndrome 1 ECG: Electrocardiogram; EEG: Electroencephalography; FISH: Fluorescence in situ hybridization; GPC3: Glypican 3; GPC4: Glypican 4; Hhsignaling: Hedgehog signaling; IGF: Insulin-like growth factor; IGF-II: Insulin-like growth factor 2: MLPA: Multiplex ligation probe amplification; MRI: Magnetic resonance imaging; NGS: Next generation sequencing; PTEN: Phosphatase and Tensin; SGBS: Simpson-golabi-behmel syndrome.

\section{Competing interest}

The authors declare that they have no competing interests.

\section{Authors' contributions}

$\mathrm{PL}$ design and supervised the study. PL and JT wrote the manuscript. JN, JT, PA carried out the molecular genetic studies and participates in the draft of the manuscript. PL, VM, FS and SG evaluated patients and collaborate in the clinical characterization of the patients. All authors read and approved the final manuscript

\section{Acknowledgements}

The authors wish to thank all patients and families with SGBS. This work was funded by a grant of the Fondo de Investigación Sanitaria, MINECO (FIS 11/02491.

\section{Author details}

${ }^{1}$ CIBERER, Centro de Investigación Biomédica en Red de Enfermedades Raras, ISCIII, Madrid 28029, Spain. ${ }^{2}$ Molecular Endocrinology - Overgrowth Syndromes Laboratory, INGEMM, Instituto de Genética Médica y Molecular, IdiPAZ, Hospital Universitario la Paz, Universidad Autónoma de Madrid (UAM), Madrid 28046, Spain. ${ }^{3}$ Structural and Functional Genomics - INGEMM, Instituto de Genética Médica y Molecular, IdiPAZ, Hospital Universitario la Paz, Universidad Autónoma de Madrid (UAM), Madrid 28046, Spain. ${ }^{4}$ Clinical Genetics - INGEMM, Instituto de Genética Médica y Molecular, IdiPAZ- Instituto de Investigación Sanitaria del Hospital Universitario La Paz- Universidad Autónoma de Madrid- CIBERER- Centro de Investigación Biomédica en Red de Enfermedades Raras, ISCIII, Madrid 28046, Spain.

\section{Received: 11 July 2014 Accepted: 25 August 2014}

Published online: 20 September 2014

\section{References}

1. Simpson JL, Landey S, New M, German J: A previously unrecognized X-linked syndrome of dysmorphia. Birth Defects Orig Artic Ser 1975, 11:18-24.

2. Behmel A, Plochl E, Rosenkranz W: A new X-linked dysplasia gigantism syndrome: identical with the Simpson dysplasia syndrome? Human Genet 1984, 67:409-413.

3. Golabi M, Rosen L: A new X-linked mental retardation-overgrowth syndrome. Am J Med Genet 1984, 17:345-358.

4. Neri G, Marini R, Cappa M, Borrelli P, Opitz JM: Simpson-Golabi-Behmel syndrome: an X-linked encephalo-tropho-schisis syndrome. Am J Med Genet 1988, 30:287-299.

5. Brzustowicz LM, Farrell S, Khan MB, Weksberg R: Mapping of a new SGBS locus to chromosome Xp22 in a family with a severe form of Simpson-Golabi-Behmel syndrome. Am J Hum Genet 1999, 65:779-783.

6. Terespolsky D, Farrell SA, Siegel-Bartelt J, Weksberg R: Infantile lethal variant of Simpson-Golabi-Behmel syndrome associated with hydrops fetalis. Am J Med Genet 1995, 59:329-333.

7. Li CC, MCDonald SD: Increased nuchal translucency and other ultrasound findings in a case of simpson-golabi-behmel syndrome. Fetal Diagn Ther 2009, 25:211-215.

8. Villarreal DD, Villarreal H, Paez AM, Peppas D, Lynch J, Roeder $E_{,}$ Powers GC: A patient with a unique frameshift mutation in GPC3, causing Simpson-Golabi-Behmel syndrome, presenting with craniosynostosis, penoscrotal hypospadias, and a large prostatic utricle. Am J Med Genet $A$ 2013, 161A:3121-3125

9. Morita Y, Kimoto N, Ogawa H, Omata T, Morita N: Simpson-Golabi-Behmel syndrome associated with cleft palate. J Craniofac Surg 2011, 22:1917-1918.
10. Taniyama T, Kitai N, Iguchi Y, Murakami S, Yanagi M, Takada K: Craniofacial morphology in a patient with Simpson-Golabi-Behmel syndrome. Cleft Palate Craniofac J 2003, 40:550-555.

11. Lapunzina P, Badia I, Galoppo C, De Matteo E, Silberman P, Tello A Grichener J, Hughes-Benzie R: A patient with Simpson-Golabi-Behmel syndrome and hepatocellular carcinoma. J Med Genet 1998, 35:153-156.

12. Krimmel M, Reinert S: Multiple odontogenic keratocysts in mental retardation-overgrowth (Simpson-Golabi-Behmel) syndrome. $\mathrm{Br} J$ Oral Maxillofac Surg 2000, 38:221-223.

13. Agarwal M, Sharma R, Panda A, Gupta A: Laryngeal web associated with Simpson-Golabi-Behmel syndrome in a child. Anaesth Intensive Care 2009, 37:671-672.

14. Glamuzina E, Aftimos S, Keesing M, Mahadevan M: New airway and swallow manifestations of Simpson-Golabi-Behmel syndrome. Int J Pediatr Otorhinolaryngol 2009, 73:1464-1466.

15. Lin AE, Neri G, Hughes-Benzie R, Weksberg R: Cardiac anomalies in the Simpson-Golabi-Behmel syndrome. Am J Med Genet 1999, 83:378-381.

16. Penisson-Besnier I, Lebouvier T, Moizard MP, Ferre M, Barth M, Marc G, Raynaud M, Bonneau D: Carotid artery dissection in an adult with the Simpson-Golabi-Behmel syndrome. Am J Med Genet A 2008, 146A:464-467.

17. Cureton E, Guo H, Idowu O, Kim S: Hepatic vascular malformation in a patient with Simpson-Golabi-Behmel syndrome. Am J Med Genet A 2007 143A:1379-1381.

18. Poetke M, Jamil B, Muller U, Berlien HP: Diffuse neonatal hemangiomatosis associated with Simpson-Golabi-Behmel syndrome: a case report. Eur J Pediatr Surg 2002, 12:59-62.

19. Hughes-Benzie RM, Tolmie JL, McNay M, Patrick A: Simpson-Golabi-Behmel syndrome: disproportionate fetal overgrowth and elevated maternal serum alpha-fetoprotein. Prenat Diagn 1994, 14:313-318.

20. Jedraszak G, Girard M, Mellos A, Djeddi DD, Chardot C, Vanrenterghem A, Moizard MP, Gondry J, Sevestre H, Mathieu-Dramard M, Lacaille F, Demeer B: A patient with Simpson-Golabi-Behmel syndrome, biliary cirrhosis and successful liver transplantation. Am J Med Genet A 2014, 164A:774-777.

21. Kim S, Idowu O, Chen E: Choledochal cyst in Simpson-Golabi-Behme syndrome. Am J Med Genet 1999, 87:267-270.

22. Griffith $\mathrm{CB}$, Probert RC, vance $\mathrm{GH}$ : Genital anomalies in three male siblings with Simpson-Golabi-Behmel syndrome. Am J Med Genet A 2009, 149A:2484-2488

23. Van Borsel J, Baudonck N, Verhaaren H, Van Lierde K: Speech and language in Simpson-Golabi-Behmel syndrome: a case report. Genet Couns 2008, 19:241-249.

24. Day R, Fryer A: Index finger abnormalities in Simpson-Golabi-Behmel syndrome. Clin Dysmorphol 2005, 14:35-36.

25. Garavelli L, Gargano G, Simonte G, Rosato S, Wischmeijer A, Melli N, Braibanti S, Gelmini C, Forzano F, Pietrobono R, Pomponi MG, Andreucci E, Toutain A, Superti-Furga A, Neri G: Simpson-Golabi-Behmel syndrome type 1 in a 27-week macrosomic preterm newborn: the diagnostic value of rib malformations and index nail and finger hypoplasia. Am J Med Genet A 2012, 158A:2245-2249.

26. Rodriguez-Criado G, Magano L, Segovia M, Gurrieri F, Neri G, Gonzalez-Meneses A, Gomez De Terreros I, Valdez R, Gracia R, Lapunzina P: Clinical and molecular studies on two further families with Simpson-Golabi-Behmel syndrome. Am J Med Genet A 2005, 138A:272-277.

27. Young EL, Wishnow R, Nigro MA: Expanding the clinical picture of Simpson-Golabi-Behmel syndrome. Pediatr Neurol 2006, 34:139-142.

28. Paludetti G, Zampino G, Della Marca G, Di Girolamo S, Scarano E, Rigante M: The tongue-base suspension using Repose bone screw system in a child with Simpson-Golabi-Behmel syndrome. Case report. Int J Pediatr Otorhinolaryngol 2003, 67:1143-1147.

29. Savarirayan R, Bankier A: Simpson-Golabi-Behmel syndrome and attention deficit hyperactivity disorder in two brothers. J Med Genet 1999, 36:574-576.

30. Mariani S, lughetti L, Bertorelli R, Coviello D, Pellegrini M, Forabosco A, Bernasconi S: Genotype/phenotype correlations of males affected by Simpson-Golabi-Behmel syndrome with GPC3 gene mutations: patient report and review of the literature. J Pediatr Endocrinol Metab 2003 16:225-232.

31. Hughes-Benzie RM, Pilia G, Xuan JY, Hunter AG, Chen E, Golabi M, Hurst JA, Kobori J, Marymee K, Pagon RA, Punnett HH, Schelley S, Tolmie JL, Wohlferd MM, Grossman T, Schlessinger D, MacKenzie AE: Simpson-Golabi-Behmel syndrome: genotype/phenotype analysis of 18 affected males from 7 unrelated families. Am J Med Genet 1996, 66:227-234. 
32. Lapunzina P: Risk of tumorigenesis in overgrowth syndromes: a comprehensive review. Am J Med Genet C Semin Med Genet 2005, 137C:53-71

33. Kosaki R, Takenouchi T, Takeda N, Kagami M, Nakabayashi K, Hata K, Kosaki K: Somatic CTNNB1 mutation in hepatoblastoma from a patient with Simpson-Golabi-Behmel syndrome and germline GPC3 mutation. Am J Med Genet A 2014, 164A:993-997.

34. Mateos ME, Beyer K, Lopez-Laso E, Siles JL, Perez-Navero JL, Pena MJ, Guzman J, Matas J: Simpson-Golabi-Behmel syndrome type 1 and hepatoblastoma in a patient with a novel exon 2-4 duplication of the GPC3 gene. Am J Med Genet A 2013, 161A:1091-1095.

35. Buonuomo PS, Ruggiero A, Vasta I, Attina G, Riccardi R, Zampino G: Second case of hepatoblastoma in a young patient with Simpson-Golabi-Behmel syndrome. Pediatr Hematol Oncol 2005, 22:623-628.

36. Thomas M, Enciso V, Stratton R, Shah S, Winder T, Tayeh M, Roeder E: Metastatic medulloblastoma in an adolescent with Simpson-Golabi-Behmel syndrome. Am J Med Genet A 2012, 158A:2534-2536.

37. Orth U, Gurrieri F, Behmel A, Genuardi M, Cremer M, Gal A, Neri G: Gene for Simpson-Golabi-Behmel syndrome is linked to HPRT in Xq26 in two European families. Am J Med Genet 1994, 50:388-390.

38. Punnett HH: Simpson-Golabi-Behmel syndrome (SGBS) in a female with an X-autosome translocation. Am J Med Genet 1994, 50:391-393.

39. Romanelli V, Arroyo I, Rodriguez JI, Magano L, Arias P, Incera I, GraciaBouthelier R, Lapunzina P: Germinal mosaicism in Simpson-Golabi-Behmel syndrome. Clin Genet 2007, 72:384-386.

40. Waterson J, Stockley TL, Segal S, Golabi M: Novel duplication in glypican-4 as an apparent cause of Simpson-Golabi-Behmel syndrome. Am J Med Genet A 2010, 152A:3179-3181.

41. Budny B, Chen W, Omran H, Fliegauf M, Tzschach A, Wisniewska M, Jensen LR, Raynaud M, Shoichet SA, Badura M, Lenzner S, Latos-Bielenska A, Ropers $\mathrm{HH}$ : A novel X-linked recessive mental retardation syndrome comprising macrocephaly and ciliary dysfunction is allelic to oral-facial-digital type I syndrome. Hum Genet 2006, 120:171-178.

42. Romanelli V, Magano L, Segovia M, Cosentino V, González-Meneses A, Del Campo M, Pérez-Jurado L, Giovannucci-Uzielli M, Soler V, Sanchís A, Arias P, Incera I, García-Bouthelier R, Lapunzina P: The OFD1 (CXORF5) gene at $\mathrm{Xp} 22$ is not mutated in a subset of Simpson-Golabi-Behmel syndrome patients. Curr Top Genet 2008, 3:45-47.

43. Filmus J, Capurro M: The role of glypicans in Hedgehog signaling. Matrix Biol 2014, 35:248-252.

44. Cano-Gauci DF, Song HH, Yang H, McKerlie C, Choo B, Shi W, Pullano R, Piscione TD, Grisaru S, Soon S, Sedlackova L, Tanswell AK, Mak TW, Yeger H, Lockwood GA, Rosenblum ND, Filmus J: Glypican-3-deficient mice exhibit developmental overgrowth and some of the abnormalities typical of Simpson-Golabi-Behmel syndrome. J Cell Biol 1999, 146:255-264.

45. Song HH, Shi W, Filmus J: OCl-5/rat glypican-3 binds to fibroblast growth factor-2 but not to insulin-like growth factor-2. J Biol Chem 1997, 272:7574-7577.

46. Chiao E, Fisher P, Crisponi L, Deiana M, Dragatsis I, Schlessinger D, Pilia G, Efstratiadis A: Overgrowth of a mouse model of the Simpson-Golabi-Behmel syndrome is independent of IGF signaling. Dev Biol 2002, 243:185-206.

47. Capurro Ml, Xu P, Shi W, Li F, Jia A, Filmus J: Glypican-3 inhibits Hedgehog signaling during development by competing with patched for Hedgehog binding. Dev Cell 2008, 14:700-711

48. Williams EH, Pappano WN, Saunders AM, Kim MS, Leahy DJ, Beachy PA: Dally-like core protein and its mammalian homologues mediate stimulatory and inhibitory effects on Hedgehog signal response. Proc Natl Acad Sci USA 2010, 107:5869-5874.

49. Lapunzina P, Lopez RO, Rodriguez-Laguna L, Garcia-Miguel P, Martinez AR, Martinez-Glez V: Impact of NGS in the medical sciences: Genetic syndromes with an increased risk of developing cancer as an example of the use of new technologies. Genet Mol Biol 2014, 37:241-249.

50. Golabi M, Leung A, Lopez C: Simpson-Golabi-Behmel Syndrome Type 1. In GeneReviews(R). Edited by Pagon RA, Adam MP, Ardinger HH, Bird TD, Dolan CR, Fong CT, Smith RJH, Stephens K. Seattle (WA): University of Washington; 1993.

51. Chen CP: Prenatal findings and the genetic diagnosis of fetal overgrowth disorders: Simpson-Golabi-Behmel syndrome, Sotos syndrome, and Beckwith-Wiedemann syndrome. Taiwan J Obstet Gynecol 2012, 51:186-191.

52. Weichert J, Schroer A, Amari F, Siebert R, Caliebe A, Nagel I, Gillessen-Kaesbach G, Mohrmann I, Hellenbroich Y: A 1 Mb-sized microdeletion Xq26.2 encompassing the GPC3 gene in a fetus with Simpson-Golabi-Behmel syndrome Report, antenatal findings and review. Eur J Med Genet 2011, 54:343-347.

53. Yamashita $H$, Yasuhi I, Ishimaru T, Matsumoto T, Yamabe T: A case of nondiabetic macrosomia with Simpson-Golabi-Behmel syndrome: antenatal sonographic findings. Fetal Diagn Ther 1995, 10:134-138.

54. Choyke PL, Siegel MJ, Craft AW, Green DM, DeBaun MR: Screening for Wilms tumor in children with Beckwith-Wiedemann syndrome or idiopathic hemihypertrophy. Med Pediatr Oncol 1999, 32:196-200.

doi:10.1186/s13023-014-0138-0

Cite this article as: Tenorio et al:: Simpson-Golabi-Behmel syndrome types

I and II. Orphanet Journal of Rare Diseases 2014 9:138.

\section{Submit your next manuscript to BioMed Central and take full advantage of:}

- Convenient online submission

- Thorough peer review

- No space constraints or color figure charges

- Immediate publication on acceptance

- Inclusion in PubMed, CAS, Scopus and Google Scholar

- Research which is freely available for redistribution 